\title{
Pasienters kroniske \\ smerter kan være usynlig for sykepleiere
}

Gjennom dialog med pasientene kan sykepleiere lære mer om kjennetegn ved kroniske smerter, bruk av smertestillende medisiner og vurdering av smerter.

\section{Caroline Heggen}

Sykepleier

Hjemmesykepleien i Færder kommune

\section{Astrid Danielsen}

Høgskolelektor og stipendiat

Universitetet i Sørøst-Norge, campus Vestfold

Smerte Empati Sykepleier-pasient-forhold**

\section{Hovedbudskap}

Kroniske smerter kjennetegnes av at de ikke er synlige, og at det ikke finnes objektive funn som kan bekrefte dem. Pasienter forteller at sykepleiere mangler forståelse for deres smerteerfaringer, og at relasjonen mellom dem er lite omsorgspreget. Forskning viser at når relasjonen preges av gjensidig forståelse og respekt, bedres pasientenes evne til å mestre smertene. 
Smerte er av International Association for the Study of

Pain definert som «en ubehagelig sensorisk og emosjonell opplevelse assosiert med aktuell eller potensiell vevsskade, eller beskrevet som slik skade».

Definisjonen tydeliggjør at smerte er en subjektiv og ubehagelig følelse, uavhengig av om det foreligger en synlig vevsskade eller ikke $(1,2)$.

Smerte forbindes med både fysiologiske og adferdsmessige endringer som bekrefter at smerten er til stede, og hvor alvorlig den er. Figur 1 viser hvordan kroppen tilpasser seg smerte over tid. Å ikke uttrykke eller ikke ha fysiske reaksjoner på smerte betyr altså ikke fravær av smerte (3).

Figur 1. Akutt smertereaksjon sett i forhold til tilpasning

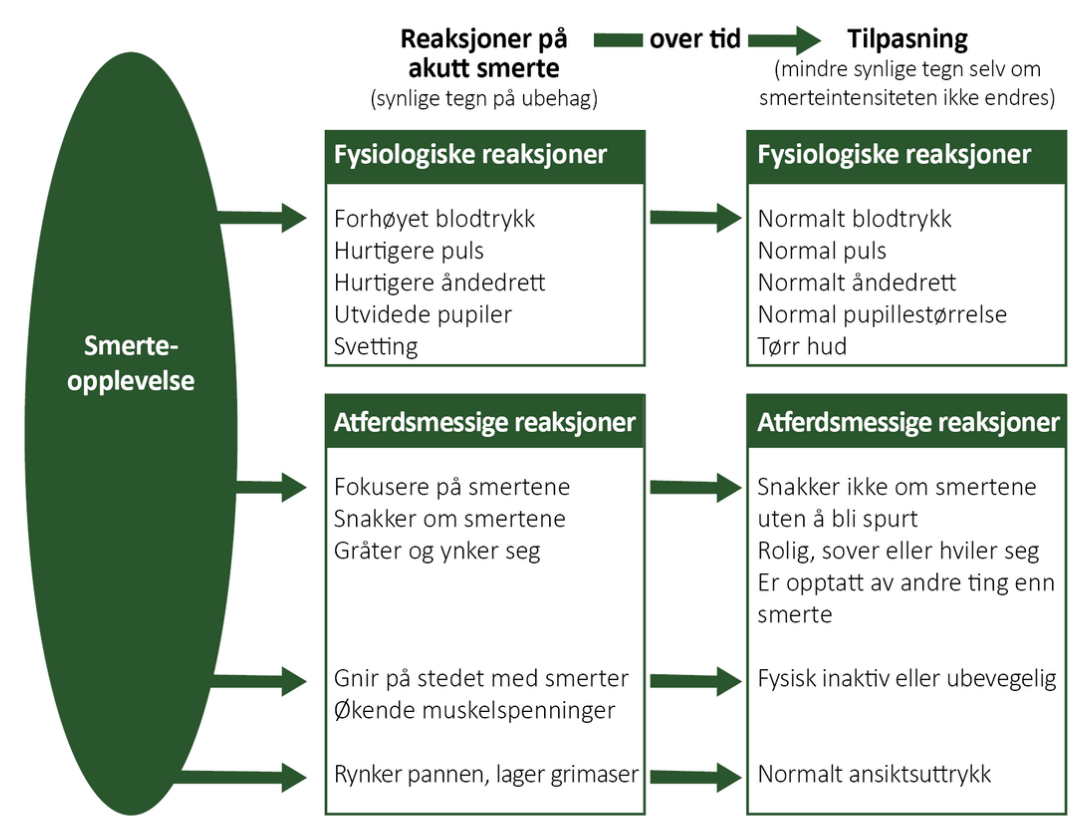

Modifisert etter Brunner og Sudarth 1988.

Kilde: McCaffery M, Beebe A. Smerter. Lærebok for helsepersonell. Oslo: Gyldendal Akademisk; 2001.

Å skape så gode relasjoner som mulig er viktig i smertebehandling. En pasients forventning til en behandling eller et medikament ser ut til å ha konsekvenser for opplevelsen av smerte. 
I en relasjon preget av tillit og respekt kan sykepleieren forklare pasienten viktigheten av en spesifikk behandling eller et medikament og dermed legge til rette for en positiv behandlingseffekt (4). Det kalles også placeboeffekt, som er knyttet til forventninger om at noe skal ha en effekt.

Det motsatte av placebo er nocebo. Om pasienten føler mistillit og er skeptisk til behandlingen eller sykepleieren, reduseres virkningen, og man kan få en negativ behandlingseffekt (3-6).

\section{Sykepleierens rolle kan være krevende}

A utføre sykepleie til pasienter med kronisk smerte er krevende og må innbefatte psykologiske, biologiske og sosiale forhold. Å hjelpe pasienten til å bli «smertefri» kan ofte være et urealistisk mål (7).

Viktige sykepleiefunksjoner er å bidra til bedre smerteforståelse som et ledd i å utvikle pasientens mestringsstrategier slik at de kan leve bedre med smertene $(5,8-9)$.

Sykepleiere er ansvarlig for å implementere både medikamentelle og ikke-medikamentelle tiltak samt å evaluere tiltakenes effekt. Å etablere en åpen og ærlig relasjon til pasienten er viktig for å skape en positiv holdning til verdien av ulike tiltak og kunne vurdere effektene av tiltakene $(5,9)$.

\section{Omsorg er både holdning og handling}

Sykepleieomsorg viser seg i det gjensidige forholdet og samhandlingen mellom sykepleieren og pasienten. Martinsen fremhever respekt, tillit og empati som fundament for god relasjonell samhandling.

En tillitsfull relasjon kan åpne for fortrolige dialoger og føre til at pasienter med kroniske smerter får bedre forståelse for smertene, og dermed muligheter for å mestre en vanskelig livssituasjon bedre $(10,11)$. 
Omsorg er ikke bare en grunnleggende holdning som sykepleieren møter pasienten med. Det er også en praktisk handling som kan innebære å gi pasienten smertestillende medisin basert på oppdatert kunnskap om smertebehandling.

Omsorg har også en moralsk dimensjon som Martinsen mener er overordnet. Det moralske består i å være i bevegelse fra seg selv til den andre og handle til den andres beste ut fra pasientens verdier og problemer $(10,12)$.

Hva som er den andres beste for en som lider av kroniske smerter, kan være utfordrende å finne ut av. Sykepleieren og pasienten må utforske det i en åpen og innlevende relasjon og samtale (11).

\section{Utvalg av forskningsartikler}

Målet med studien var å unders $\varnothing$ ke hvordan pasienter erfarer kroniske smerter i sammenheng med relasjonen til sykepleieren. For å finne relevant forskning gjorde vi systematiske $s \varnothing \mathrm{k}$ i Oria, McMaster, CINAHL, PubMed og PsycINFO.

Vi benyttet også PsycINFO fordi kroniske smertepasienter også kan ha psykiatriske diagnoser, som igjen kan være av betydning for relasjonen til sykepleieren. Vi gjorde i tillegg søk på «chronic pain» i UpToDate og BMJ Best Practice.

Forskningsartiklene vi inkluderte i første omgang, var engelskspråklige, fagfellevurderte artikler som var publisert fra 2005, og som hadde en tydelig relasjon til sykepleie gjennom forfatternes arbeidssted eller tittel som «registered nurse» $(\mathrm{RN})$. De var også registrert $\mathrm{i}$ Norsk senter for forskningsdata i 2019.

Vi ekskluderte fagartikler og forskningsartikler som omhandlet spesifikke temaer knyttet til en bestemt smertediagnose eller malign smerte, eller som ble antatt å ha lav overføringsverdi til norsk helsevesen grunnet kulturelle ulikheter. 


\section{Pasientene føler at relasjonen er vanskelig}

Gjennomgang av forskningslitteraturen viser at kroniske smerter kjennetegnes av usynlighet og mangel på objektive funn som kan forklare smertene.

En konsekvens er at pasientene føler at sykepleierne ikke har tillit til deres smerteopplevelser. De erfarer at relasjonen er vanskelig og lite omsorgspreget (13, 14, 18).

På den andre siden er det forskningsfunn som viser den positive betydningen av en tillitsfull, respektpreget og empatisk relasjon som omhandler pasientens håndtering av sine smerter $(13,14,16-18)$.

\section{Er forventningene til sykepleie for høye?}

Dersom pasientene følte at tillit var grunntonen i relasjonen, erfarte de at sykepleierne forsto alvoret $\mathrm{i}$ deres livssituasjon. Det innebar også at de følte seg sett og forstått som hele mennesker det var verdt å ta på alvor (16-18).

Det motsatte var tilfellet når negativitet preget relasjonen til sykepleierne. Pasientene rapporterte at de følte seg «sutrete og klagete» og ikke tålte smerte, og at de ikke ble tatt på alvor.

For å opprettholde interessen fra sykepleierne hevdet pasientene at de måtte være sta, ikke gi seg og være aktive ved å informere sykepleierne om unders $\varnothing$ kelser de mente kunne lette smertene og gi lindrende behandling.

\section{«Mange av pasientene som deltok i studiene, følte at måten de ble behandlet på, var skuffende og stressende.»}


Nielsen og medarbeidere bekrefter at mangel på engasjement fra sykepleiere kan være et problem (14). En pasient beskrev at konsultasjoner med en sykepleier var ydmykende, og at sykepleieren så på hennes smerte som et psykosomatisk problem fordi det ikke skyldtes identifiserbare årsaker.

Mange av pasientene som deltok i studiene, følte at måten de ble behandlet på, var skuffende og stressende. De uttrykte frustrasjon over at fors $\varnothing$ kene på å forklare smerter ikke lyktes.

Pasientene manglet ord og begreper for å karakterisere smerten på en adekvat måte og trodde at samtalene med sykepleierne kunne bidra til en bedre forståelse av hverdagen med kroniske smerter.

\section{Kunnskapsmangel var en barriere}

Studiene viser at sykepleiere både $\varnothing$ nsket og trengte mer kunnskap om smerte generelt og det komplekse ved kronisk smerte spesielt. De hadde begrenset forståelse for egenarten ved kronisk smerte, for pasienter med kronisk smerte og for pasientpleierrelasjonens betydning for pasientenes smertemestring (14-17).

Sykepleierne rapporterte at den viktigste barrieren for å yte god omsorg til pasienter med kronisk smerte er kunnskapsmangel (14-17). De mener selv at de trenger kunnskap om å:

- bruke smertestillende medisin

- unders $\varnothing \mathrm{ke}$ og vurdere smerte

Flere forskere peker på at sykepleierne ikke var tilfreds med sin egen innsats i smertebehandling, og relaterte det til mangel på kunnskap og opplæring. Det er gjort store fremskritt innen forskning, men problemet er omsetting av eksisterende forskning til kunnskapsbasert praksis. 
Litteraturen peker også på at smerte ikke bare må anses som et medisinsk problem, men forstås i en bredere sammenheng hvor sosiale, psykologiske og kulturelle perspektiver trekkes inn.

Forskning beskriver biopsykososial (fysiologisk, psykologisk og sosial) tilnærming som en god måte å forstå kompleksiteten ved kronisk smerte på (14).

\section{Synlig smerte er lettere å forstå}

Oppdatert kunnskap er essensielt for sykepleieres evne til innlevelse i møte med pasienter med kronisk smerte (15). Flere studier påpeker at en positiv og åpen holdning overfor pasienten og hans eller hennes problemer vil resultere i bedre smertelindring (13, 14, 16-18).

Paul-Savoie og medarbeidere tydeliggjør at sykepleiere stoler mer på sin egen vurdering av pasientens smerte enn det pasienten selv formidler (17). Dette begrenser sykepleiernes interesse for å utforske smerten sammen med pasienten.

Funn fra den samme studien viser at sykepleiere vurderer seg selv som mer empatiske i sin sykepleieut $\varnothing$ velse enn en nøytral observat $\varnothing r$ konkluderer med. Studien viser også at sykepleiere er mer empatiske og viser større forståelse og innlevelse for pasienter med synlige smertetegn som deformerte ekstremiteter, sår og skader enn pasienter med «usynlig» smerte.

Forskerne fant at sykepleierne som inngikk i deres studie, ofte søkte en patologisk forklaring på pasientens smerter, noe Nielsen og medarbeidere bekrefter i sin studie (14). Det usynlige ved den kroniske smerten gjør det viktig å utdanne sykepleiere til å nærme seg pasienten på andre måter enn å søke identifiserbar patologi på kronisk smerte. 


\section{En diagnose gjør usynlig smerte mer synlig}

Denne studien hadde som utgangspunkt et spørsmål om pasient-sykepleierrelasjonens betydning for pasientens kroniske smerter.

Kari Martinsens omsorgsforståelse har gitt inspirasjon til undersøkelsen, som er basert på funn i forskningslitteratur. I forskningslitteraturen finner vi beskrivelser av pasientenes opplevelse av å leve med kronisk smerte i møte med sykepleiere.

Funnene viser at når pasienten opplevde en tillitsskapende relasjon, ga det ham eller henne følelsen av å være troverdig og bli tatt på alvor. Det ga en følelse av kontroll og forutsigbarhet i smertehåndteringen $(14,16,18)$.

\section{«Pasienter beskrev at det var betydningsfullt å få en diagnose.»}

Det motsatte ble også dokumentert. En forbeholden tilnærming fra sykepleierens side hadde negative konsekvenser for pasienten i form av mangel på tillit til sykepleieren og en følelse av mindreverd $(16,18)$.

Forskerne dokumenterte hvordan smertens usynlighet svekket pasientens troverdighet og følelse av ivaretakelse i møte med sykepleieren $(14,17,18)$. Både pasienten selv og sykepleieren lette etter synlighet $i$ form av patologi for å kunne forklare og synliggjøre smertetilstanden både for seg selv og omverdenen.

Pasienter beskrev at det var betydningsfullt å få en diagnose. Pasienten søkte aktivt å få bekreftet at opplevelsen av kronisk smerte ikke var innbilt, men reell $(5,19)$. 


\section{Pasientene må sette ord på sin smerte}

Et tilleggsmoment som kan bidra til å usynliggjøre kronisk smerte, er kroppens fysiske og psykiske tilpasning til smerte over tid. En pasient med kronisk smerte uttrykker ikke smerte verbalt om han eller hun ikke direkte oppfordres til det (3).

Pasienten sover, hviler og uttrykker interesse for andre ting enn smerte. Dette er en tilpasningsstrategi som er fysiologisk hensiktsmessig (jf. figur 1), men som samtidig bidrar til å usynliggjøre smerten for andre.

Sykepleiere må ha kunnskap om denne fysiologiske tilpasningen til kronisk smerte for å evne å møte pasienten og se hans eller hennes behov for sykepleie.

Det bekreftes av Nortvedt og Nortvedt (20), som argumenterer for at sykepleiere ikke kan trekke konklusjoner gjennom observasjon av hvordan pasientene fremstår, deres oppførsel eller handlingsm $\varnothing$ nster.

Sykepleiere må aktivt oppfordre pasientene til å snakke om sin smerte og hjelpe dem til å sette ord på sine smerteerfaringer.

\section{Forståelsesmodeller er ikke gode nok}

Sykepleiere har fors $\varnothing \mathrm{kt}$ å anvende biopsykososiale forståelsesmodeller i møte med kroniske smertepasienter $(7,14)$. Det er modeller som utforsker integrasjonen mellom pasientens biologiske og psykologiske dimensjoner sett i sammenheng med hans eller hennes sosiale forhold.

Til tross for utvikling og bruk av slike modeller beskriver forskning at pasientene fortsatt erfarer å ikke bli møtt og godt nok ivaretatt. 
Det er grunn til å anta at det mangler forståelsesmodeller som fremhever betydningen av relasjonen mellom pasienten og sykepleieren, og som kan aktivere kunnskap om hvordan tanker, opplevelser og sansestimuli bidrar til opplevelsen av kronisk smerte (2).

\section{Gode relasjoner kan lindre smerter}

Kroniske smertepasienter utfordrer sykepleierens forståelse av smerte og hvordan hun eller han skal forholde seg til pasienten. Symptomer og tegn på smerte er tildekket, og pasienten fremstår på mange måter som «frisk» (5).

Litteraturstudien viser at en god omsorgsrelasjon mellom sykepleieren og pasienten har positiv effekt på pasientens smerter $(14,16,18)$. Der pasienten erfarer at sykepleieren er distansert og uengasjert, vil vedkommende kunne oppleve økende smerter og flere hindre mot lindring $(14,16,17)$.

\section{«Sykepleieren har ikke direkte tilgang til pasientens subjektive smerte.»}

Sykepleieren har ikke direkte tilgang til pasientens subjektive smerte (2), men kan hjelpe pasienten med å sette ord på smerten og skape mening i hans eller hennes erfaringer og derved bidra til en positiv relasjon. Det vil kunne gi smertelindring (21).

$\AA$ ha en omsorgsforankret tilnærming til pasienter med kronisk smerte, inkludert kunnskap om smertefysiologi og kroppens tilpasningsdyktighet samt klinisk erfaring, vil være av betydning for å hjelpe pasienten til å sette ord på og håndtere sin kroniske smerte. Dessuten er det avgjørende å ha forståelse for selve omsorgsrelasjonens betydning for smertelindring. 


\section{Konklusjon}

Omsorgsrelasjonen mellom sykepleieren og pasienten med kronisk smerte er viktig. Hvis forholdet er tillitsfullt, åpent og utforskende, kan pasienten utvikle sine evner til å mestre kroniske smerter bedre.

En positiv relasjon utløser også fysiologiske smertemekanismer som demper smerten. Kronisk smerte er usynlig og kan ikke dokumenteres som påviselig sykdom.

Følgelig har sykepleiere behov for teorier som setter søkelys på flerdimensjonale sykdomsforståelser og kunnskap om kroniske smerter. Det er behov for mer forskning om sykepleieres relasjon til pasientens kroniske smerter og samspillets betydning for smertene.

Det er nødvendig å styrke sykepleieres kunnskap om kronisk smerte og omsorgsrelasjonens betydning. Det vil være i tråd med sykepleieres ansvar og plikt til å ivareta pasientens verdighet og styrke vedkommendes tillit til profesjonen.

\section{Referanser}

1. Nortvedt F, Leegaard, M, Valeberg B, Helseth S. Livskvalitet og smerte - begrep og fenomen. I: Helseth S, Leegaard M, Nortvedt F, red. Livskvalitet og smerte - et mangfoldig forskningsfelt. Oslo: Gyldendal akademisk; 2016. s. 11-24.

2. Stubhaug A, Ljosa TM. Hva er smerte? I: Rustøen T, Wahl AK, red. Ulike tekster om smerte - fra nocisepsjon til livskvalitet. Oslo: Gyldendal akademisk; 2008. s. 22-50.

3. McCaffery M, Beebe A. Smerter. Oslo: Gyldendal akademisk; 1996. 
4. Rütgen M, Seidel EM, Silani G, Riečanský I, Hummer A, Windischberger C, et al. Placebo analgesia and its opiodergic regulation suggest that empathy for pain is grounded in selv pain. Proceedings of the National Academy of Sciences; 2015 september. Tilgjengelig fra:

https://www.pnas.org/content/112/41/E5638 (nedlastet 16.01.2020).

5. Danielsen A, Berntzen H, Almås H. Sykepleie ved smerter. I: Stubberud DG, Grønseth R, Almås H, red. Klinisk sykepleie. 5. utg. Oslo: Gyldendal akademisk; 2016. s. 381-428.

6. Winger A, Leegard M. Smerter. I: Heggestad AKT, Knutstad U, red. Sentrale begreper og fenomener i klinisk sykepleie. 4. utg. Oslo: Cappelen Damm Akademisk; 2016. s. 172-97.

7. Rosenquist EWK, Aronson MD, Crowley M.

Evaluation of chronic pain in adults. Helsebiblioteket:

UpToDate; 2018 oktober. Tilgjengelig fra:

https://www.uptodate.com/contents/search?

search=evaluation-of-chronic-pain-inadults\&sp=o\&searchType=PLAIN_TEXT\&source=USE R_INPUT\&searchControl=TOP_PULLDOWN\&search Offset $=1 \&$ autoComplete $=$ false\&language $=\& \max =0$ \&in dex=\&autoCompleteTerm $=$ (nedlastet 21.04.2020).

8. Nortvedt F, Rustøen T. Kronisk smerte. I: Rustøen $\mathrm{T}$, Wahl AK, red. Ulike tekster om smerte - fra nocisepsjon til livskvalitet. Oslo: Gyldendal akademisk; 2008. s. 140-151.

9. Rosenquist EWK, Aronson MD, Crowley M.

Overview of the treatment of chronic non-cancer pain. Helsebiblioteket: UpToDate; 2019 februar. Tilgjengelig fra: https://www.uptodate.com/contents/overview-ofthe-treatment-of-chronic-non-cancer-pain (nedlastet 21.04.2020).

10. Martinsen K. Samtalen, skjønnet og evidensen.

Oslo: Akribe; 2005. 
11. Nortvedt P. Omtanke - en innføring i sykepleiens etikk. Oslo: Gyldendal akademisk; 2016.

12. Alvsvåg H. Omsorg - med utgangspunkt i Kari Martinsens omsorgstenkning. I: Heggestad AKT, Knutstad U, red. Sentrale begreper og fenomener i klinisk sykepleie 4. utg. Oslo: Cappelen Damm Akademisk; 2016. s. 346-80.

13. Heggen C. Relasjon som smertelindring - om omsorgsrelasjonens betydning for pasienter med kroniske smerter. Tønsberg: Universitetet i SørøstNorge; 2019. s. 1-50.

14. Nielsen M, Foster M, Henman P, Strong J. Talk to us like we're people, not an X-ray': the experience of receiving care for chronic pain. Australian Journal of Primary Health. 2016 april;19(2):138-43.

15. Bergeron DA, Bourgault P, Gallagher F. Knowledge and beliefs about chronic non-cancer pain management for family medicine group nurses. American Society for Pain Management Nursing. 2015 desember;16(6):951-8.

16. Jonsdottir T, Gunnarsdottir S, Oskarsson GK, Jonsdottir H. Patients' perception of chronic painrelated patient-provider communication in relation to sociodemograpic and pain-related variables: a crosssectional nationwide study. American Society for Pain Management Nursing. 2016;17(5):322-32.

17. Paul-Savoie E, Bourgault P, Potvin S, Gosselin E, Lafrenaye S. The impact of Pain invisibility on patientcentered care and empathetic attitude in chronic pain management. Pain Research and Management; 2018 september.

18. Hansson KS, Fridlund B, Brunt D, Hansson B, Rask M. The meaning of the experiences of persons with chronic pain in their encounters with the health service. Scandinavian Journal of Caring Sciences. 2011 oktober;11(25):444-50. 
19. Clarke KA, Iphofen R. Believing the patient with chronic pain: a review of the literature. British Journal of Nursing. 2005;14(9):490-3.

20. Nortvedt F, Nortvedt P. Smerte - fenomen og etikk. Oslo: Gyldendal akademisk; 2018.

21. Nortvedt F. Innelukket i smerte - utestengt fra verden. Sykepleien. 2011;8:74-5. 